\title{
Water quality assessments of the river Gorveshwari in Dinajpur, Bangladesh
}

\author{
ZANNATUL FERDOUSHI*, MD ABUL KALAM AZAD, MD. SHAMIM RAHMAN \\ AND MST NAHID AKTER ${ }^{1}$ \\ Department of Fisheries Management \\ Hajee Mohammad Danesh Science \& Technology University (HSTU), Dinajpur, Bangladesh \\ ${ }^{1}$ Department of Aquaculture, HSTU, Dinajpur, Bangladesh \\ *Corresponding Author: zannatul99bd@yahoo.com
}

\begin{abstract}
A study was carried out to assess planktonic community with some physico-chemical parameters of the Gorveshwari river in Dinajpur district of Bangladesh. Fortnight water samplings were performed at four sites. Findings revealed that water temperature, water level and transparency were within the optimal ranges$14.33-31.23^{\circ} \mathrm{C}, 1.38-3.97 \mathrm{~m}$ and $43.32-88.67 \mathrm{~cm}$ respectively. The values of dissolved oxygen, $\mathrm{pH}$, total alkalinity and total dissolved solids were found to vary $7.16-9.32 \mathrm{ppm}, 6.37-8.93,28.07-39.56 \mathrm{ppm}$ and 59.87-133.74 ppm in the four sampling sites respectively. From plankton analysis, 36 genera of plankton were identified of which 27 genera were phytoplankton groups and 9 genera were zooplankton. Among them, Chlorophyceae ranked the first position with highest abundance $3.11 \pm 0.12 \times 10^{3} \mathrm{cells} / \mathrm{L}$. Euglenophyceae was recorded as the minor group of phytoplankton both in number and density. On the other hand, abundance of Rotifera was found to be higher in number $\left(0.95 \pm 0.04 \times 10^{3} \mathrm{cells} / \mathrm{L}\right)$, while, Crustacean larvae was noticed as scarcer group throughout the study period. Moreover, from correlation analysis it was observed that the abundance of total phytoplankton and total plankton were negatively correlated with water temperature and transparency where positively correlated with water level, $\mathrm{pH}$, dissolved oxygen, total dissolved solids and total alkalinity. This study concludes that the fish production suitability of Gorveshwari river is within productive range though some anthropogenic activities affecting the aquatic biodiversity were also observed throughout the sampling period.
\end{abstract}

Keywords: Gorveshwari river, Phytoplankton, Zooplankton, Water quality

\section{Introduction}

Bangladesh which has a suitable geographical location with the expected fisheries resources including the massive delta rivers like the Ganges-Brahmaputra-Meghna river system flowing throughout the country. Like other districts of Bangladesh, Dinajpur district is also blessed with many small and large rivers. Punarbhaba, Karotoya, Gorveshwari, Ichamoti, Atrai, Kankra, Dhepa are ones of them. Most of them are flooded with water during rainy seasons while in dry period they contain a little amount of water. Gorveshwari is a tributary of the Atrai river. The length of the river is $25 \mathrm{~km}$, the average width is $26 \mathrm{~m}$ and the nature of the river is serpentine. According to the data of Bangladesh Water Development Board, the identification number of Gorbheshwari river is River No. 26 in the north-western region (DoF 2019). The river serves as a perennial source of feeding, breeding and spawning ground for many indigenous fish species as well as other aquatic organisms. It supports the livelihood of the local fishing community with supplying the regional fish protein demand.

However, some unplanned management, agricultural runoff, disposal public wastage into the water and other human activities both lentic and lotic water habitats in Bangladesh are deteriorated (Nahid et al. 2020). Fish mortalities and spread out some contagious diseases are

https://doi.org/10.52168/bjf.2021.33.14 
occurred due to lack of proper guideline in water quality management as well (Nahid et al. 2020). Moreover, lack of limnological knowledge will create confusions and controversies for proper management and conservation. Changes in the water quality can alter the biotic community structure. Therefore, monitoring water quality is of immense importance for management of water quality. It involves the assessment of physico-chemical parameters of water bodies which is a function expressed as pollution parameters. A good limnological knowledge will also help to develop any sustainable aquaculture through maintaining the productive water quality parameters (Ferdoushi et al. 2019). Moreover, the baseline information on water quality aspects will be helpful for raising public awareness towards the development of any water resource as well as its conservation. To date, comprehensive work on the limnological aspects Gorveshwari river in Dinajpur district is scarce. Most of the existing data focused on Punarbhaba, Atrai, and Dhepa river of this region. Furthermore, necessary water quality information about this study river from published data is not available. Hence, this research work has been undertaken to observe the physico-chemical and plankton community of Gorveshwari river.

\section{Materials and Methods}

Description of the study area: The study was conducted to the Gorveshwari river, which is a tributary of the Atrai river of Dinajpur district in northwestern Bangladesh. Four study sites (considered as treatments) were selected along the length of the river. Two sites were located at Ramdubi in Sundorbon union (Site I and Site II) and other two sites were located at Chakchakiakum point in Fazilpur union (Site III and Site IV) (Fig. 1a and 1b). Site III and site IV were located three kilometers away from site I and site II towards the downstream of the river. Water sampling and limnological observation were done fortnightly since September 2019 to March 2020 from the selected study sites. During sampling, water collections and monitoring of different limnological parameters were performed at three points of each site or treatment, are reflecting as replications of each treatment for further statistical analysis.
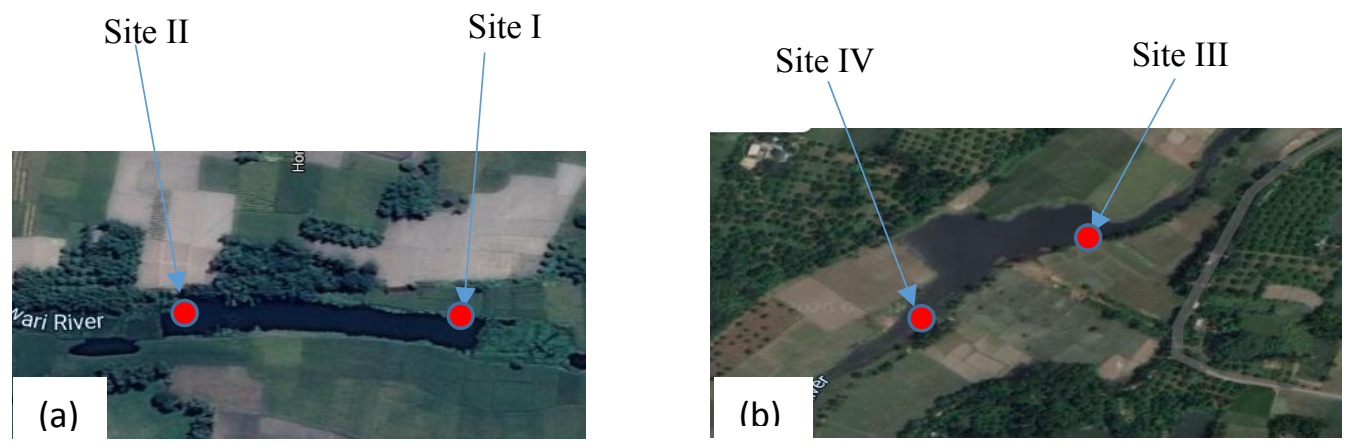

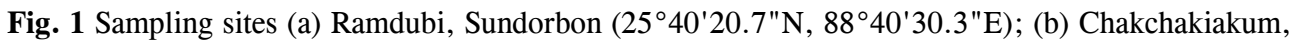
Fazilpur $\left(25^{\circ} 45^{\prime} 09.7^{\prime \prime} \mathrm{N}, 88^{\circ} 42^{\prime} 16.4^{\prime \prime} \mathrm{E}\right)$.

Determination of physico-chemical parameters: Water temperature, water level, transparency, $\mathrm{pH}$, dissolved oxygen and TDS were measured in the field using thermometer, measuring scale, secchi disk, dissolved oxygen meter (Model PDO-519, Lutron), $\mathrm{pH}$ meter (HANNA Instruments, model HI 98107) and TDS meter (TDS-3), respectively. To determine 
total alkalinity, water sample were collected from the study sites and kept in separate bottle with proper leveling, then brought to the laboratory. Total alkalinity was measured by titration method using $0.02 \mathrm{~N}$ sulfuric acid and methyl orange indicator (APHA 1992).

Plankton analysis: Plankton samples were collected for qualitative and quantitative analysis from each site of Gorveshwari river fortnightly by using plankton net with $25 \mu \mathrm{m}$ mesh size. Plankton samples were collected by filtration technique. Both phytoplankton and zooplankton samples were identified up to genus level with the help of taxonomic keys from the text book of Bellinger (1997), Pontin (1978), Lind and Brook (1980) with magnification of $10 \times 0.25$ under binocular microscope. Then plankton abundance i.e. both phytoplankton and zooplankton were estimated by applying the following formula (Rahman 1992):

$$
\text { Number of plankton }(\mathbf{N})=\frac{A * C}{F * V * L} * 1000
$$

Where, $\mathrm{N}=$ Number of plankton cells per liter, $\mathrm{A}=$ Total number of plankton counted, $\mathrm{C}=$ Volume of final concentration of samples in $\mathrm{ml}, \mathrm{V}=$ Volume of field in cubic millimeter, $\mathrm{F}=$ Number of fields counted and $\mathrm{L}=$ Volume of original water in liter.

Statistical analysis: The statistical analyses were performed using SPSS (Statistical Package for Social Science) software version 20. A one way analysis of variance (One way ANOVA) and Tukey's test were applied to data for determining significance and comparison between mean \pm SD (standard deviation).

\section{Results}

Physico-chemical parameters: No significant difference was observed in the physico-chemical parameters among the study sites of Gorveshwari river. The fortnightly variation in different physico-chemical parameters is shown by Fig. 2 (a-g). All the sites showed similar pattern of water temperature fluctuation with almost same level of ranges, though the maximum values was recorded in site III (Fig. 2a.). Water transparency ranged from 43.34 (Site I) to $88.67 \mathrm{~cm}$ (Site II) (Fig. 2b). Water level was fluctuated within the range of $1.38-3.97 \mathrm{~m}$ with mean value of $2.77 \pm 0.78,2.50 \pm 0.70,2.45 \pm 0.79$ and $2.54 \pm 0.81 \mathrm{~m}$ in site I, site II, site III and site IV, respectively (Fig. 2c).

The overall $\mathrm{pH}$ values were found to fluctuate within the range of $6.37-8.93$ in the four sampling sites (Fig. 2d). While, dissolved oxygen (DO) concentration of the experimental sites showed slight variations. The range of dissolved oxygen were 7.16-9.32 ppm with mean ( $\pm \mathrm{SD})$ values of $8.21 \pm 0.66 \mathrm{ppm}, 8.19 \pm 0.48 \mathrm{ppm}, 8.04 \pm 0.48 \mathrm{ppm}$ and $8.26 \pm 0.38 \mathrm{ppm}$ in site I, site II, site III and site IV, respectively (Fig. 2e). On the other hand, total dissolved solids of the water of Gorveshwari river were found to fluctuate from 59.87-133.74 ppm with no significant variation among the sites (Fig. 2f). Like other physico-chemical parameters, total alkalinity of the water in four sampling sites showed similar pattern of non-significant variation throughout the study period (Fig. 2g).

Plankton population: A total of 27 genera of phytoplankton belonging to four groups, Euglenophyceae, Cyanophyceae, Bacillariophyceae, and Chlorophyceae were identified in the river Gorveshawri (Table I). Among them two genera of Euglenophyceae, six genera of 
Cyanophyceae, nine genera of Bacillariophyceae and ten genera of Chlorophyceae were recorded (Table I). Table I also shows the identified composition of zooplankton. A total of nine genera were identified that included four genera of Rotifera, two genera of Copepoda, two genera of Cladocera followed by one genera of Crustacea.

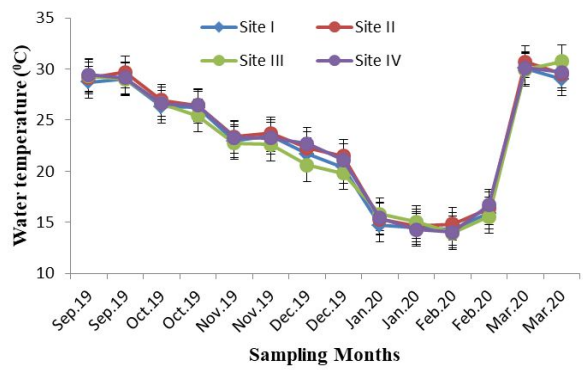

Fig. 2(a) Water temperature $\left({ }^{\circ} \mathrm{C}\right)$

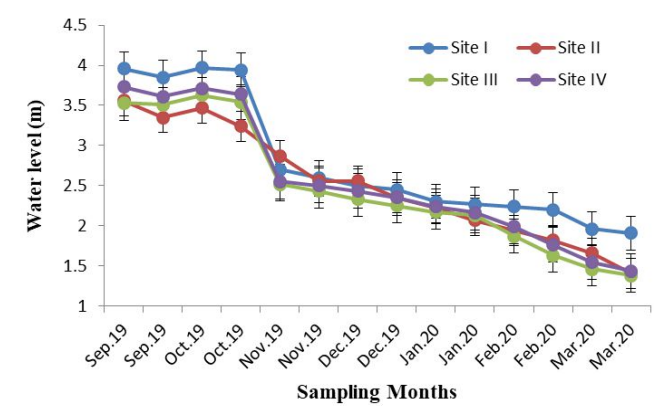

Fig. 2(c) Water level(m)

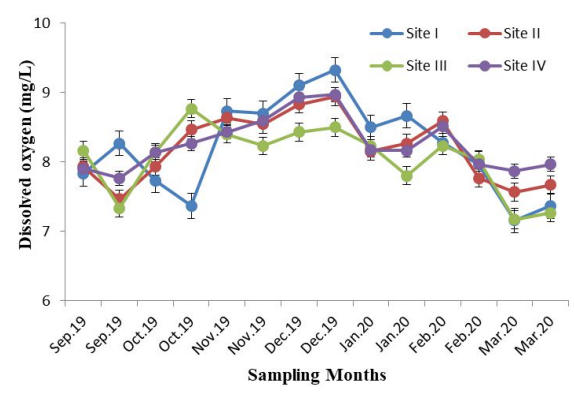

Fig. 2(e) Dissolved oxygen (ppm)

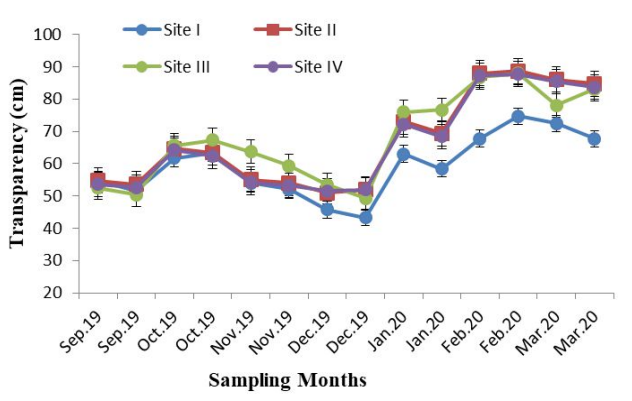

Fig. 2(b) Transparency (cm)

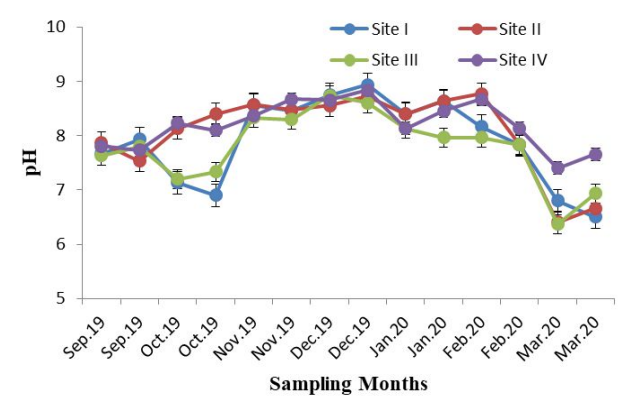

Fig. 2(d) $\mathrm{pH}$

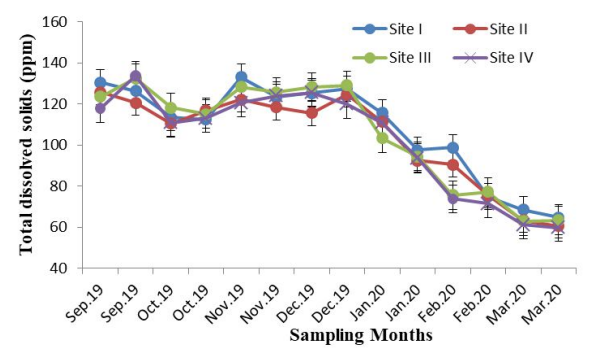

Fig. 2(f) Total dissolved solids (ppm) 


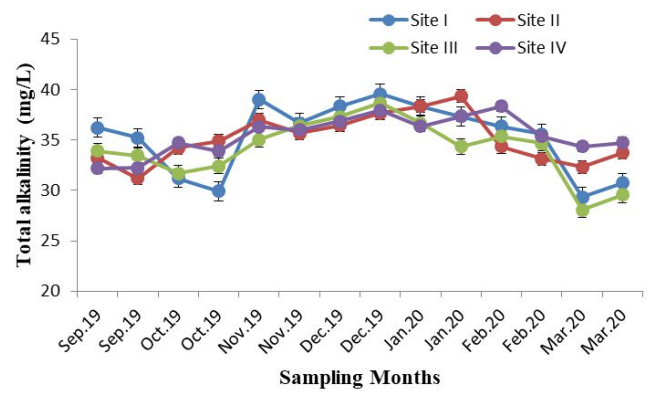

Fig. 2(g) Total dissolved solids (ppm)

Fig. 2. Fortnightly variation in physico-chemical parameters in four sampling sites; (a) water temperature $\left({ }^{\circ} \mathrm{C}\right)$, (b) Transparency (cm), (c) Water level (m), (d) pH, (e) Dissolved oxygen (ppm), (f) Total dissolved solids (ppm) and (g) Total alkalinity (ppm).

Table I. Different groups of plankton identified in four sampling sites of the Gorveshawri river

\begin{tabular}{|c|c|c|c|}
\hline Plankton Types & Groups & & Taxa \\
\hline \multirow{4}{*}{ Phytoplankton } & Bacillariophyceae & $\begin{array}{l}\text { Actinella } \\
\text { Diatoma } \\
\text { Melosira } \\
\text { Nitzchia } \\
\text { Synedra }\end{array}$ & $\begin{array}{l}\text { Cyclotella } \\
\text { Fragillaria } \\
\text { Navicula } \\
\text { Tabellaria }\end{array}$ \\
\hline & Chlorophyceae & $\begin{array}{l}\text { Ceratium } \\
\text { Closterium } \\
\text { Spirogyra } \\
\text { Microspora } \\
\text { Ulotrix }\end{array}$ & $\begin{array}{l}\text { Chlorella } \\
\text { Pediastrum } \\
\text { Synedra } \\
\text { Zygnema } \\
\text { Volvox }\end{array}$ \\
\hline & Cyanophyceae & $\begin{array}{l}\text { Anabaena } \\
\text { Microcystis } \\
\text { Oscillatoria }\end{array}$ & $\begin{array}{l}\text { Gloeocapsa } \\
\text { Nostoc } \\
\text { Spirulina } \\
\end{array}$ \\
\hline & Euglenophyceae & $\begin{array}{l}\text { Euglena } \\
\text { Phacus }\end{array}$ & \\
\hline \multirow{4}{*}{ Zooplankton } & Copepoda & $\begin{array}{l}\text { Cyclops } \\
\text { Diaptomus }\end{array}$ & \\
\hline & Cladocera & $\begin{array}{l}\text { Daphnia } \\
\text { Moina }\end{array}$ & \\
\hline & Rotifera & $\begin{array}{l}\text { Asplancha } \\
\text { Filinia }\end{array}$ & $\begin{array}{l}\text { Brachionus } \\
\text { Keratella }\end{array}$ \\
\hline & Crustacean larva & Nauplius & \\
\hline
\end{tabular}

Table II shows the mean values and ranges of different plankton groups in four sampling sites. Unlike the physico-chemical parameters, the abundance of different groups of phytoplankton as well as the total phytoplankton showed significant variation $(p<0.05)$ with the sites except Euglenophyceae. Chlorophyceae noted as first position in abundance and diversity during the sampling period. The maximum mean value of Chlorophyceae was recorded in Site I where the minimum value was recorded in Site IV (Table II). While, the lowest mean abundance 
WATER QUALITY ASSESSMENTS OF THE RIVER GORVESHWARI

of Bacillariophyceae was found in site IV and the highest abundance was observed in site I. Dominant genera of Bacillariophyceae were Cyclotella, Fragillaria, Navicula, and Tabellaria, etc. Cyanophyceae ranked the third position among the four groups. Most dominant species were Microcystis, Nostoc, Oscillatoria and Spirulina etc. The maximum mean abundance of Cyanophyceae was recorded in site I (Table II). The study showed the cell density of Euglenophyceae was relatively lower than other groups of phytoplankton with a range of 0.39 $\times 10^{3}$ cells/L to $1.29 \times 10^{3}$ cells/ $\mathrm{L}$ (Table II).

Table II. Mean values $\left( \pm\right.$ SD) and ranges of plankton $\left(\times 10^{3}\right.$ cells/L) in 4 sampling sites

\begin{tabular}{|c|c|c|c|c|c|}
\hline \multirow[t]{2}{*}{ Plankton Groups } & \multicolumn{4}{|c|}{ Sampling sites } & \multirow{2}{*}{$\begin{array}{l}\text { Level of } \\
\text { significance }\end{array}$} \\
\hline & Site I & Site II & Site III & Site IV & \\
\hline Euglenophyceae & $\begin{array}{l}0.82 \pm 0.25 \\
(0.44-1.23)\end{array}$ & $\begin{array}{l}0.76 \pm 0.28 \\
(0.43-1.29)\end{array}$ & $\begin{array}{l}0.70 \pm 0.18 \\
(0.39-0.95)\end{array}$ & $\begin{array}{l}0.62 \pm 0.19 \\
(0.29-0.97)\end{array}$ & NS \\
\hline Cyanophyceae & $\begin{array}{l}2.0 \pm 0.37^{\mathrm{a}} \\
(1.51-2.53)\end{array}$ & $\begin{array}{l}1.95 \pm 0.44^{\mathrm{a}} \\
(1.21-2.73)\end{array}$ & $\begin{array}{l}1.30 \pm 0.52^{\mathrm{b}} \\
(0.65-2.09)\end{array}$ & $\begin{array}{l}1.27 \pm 0.55^{\mathrm{c}} \\
(0.45-2.50)\end{array}$ & $* *$ \\
\hline $\begin{array}{l}\text { Bacillariophycea } \\
\text { e }\end{array}$ & $\begin{array}{l}2.03 \pm 0.56^{\mathrm{a}} \\
(1.36-2.86)\end{array}$ & $\begin{array}{l}1.80 \pm 0.50^{\mathrm{a}} \\
(1.20-2.70)\end{array}$ & $\begin{array}{l}1.07 \pm 0.35^{\mathrm{b}} \\
(0.48-1.78)\end{array}$ & $\begin{array}{l}0.91 \pm 0.32^{c} \\
(0.38-1.37)\end{array}$ & $* *$ \\
\hline Chlorophyceae & $\begin{array}{l}2.15 \pm 0.60^{\mathrm{a}} \\
(1.44-3.20)\end{array}$ & $\begin{array}{l}2.14 \pm 0.70^{\mathrm{a}} \\
(1.25-3.60)\end{array}$ & $\begin{array}{l}1.38 \pm 0.49^{b} \\
(0.88-2.44)\end{array}$ & $\begin{array}{l}1.20 \pm 0.37^{\mathrm{c}} \\
(0.71-2.04)\end{array}$ & $* *$ \\
\hline Copepoda & $\begin{array}{l}0.47 \pm 0.07^{\mathrm{a}} \\
(0.35-0.56)\end{array}$ & $\begin{array}{l}0.45 \pm 0.18^{\mathrm{a}} \\
(0.23-0.97)\end{array}$ & $\begin{array}{l}0.37 \pm 0.07^{\mathrm{a}} \\
(0.25-0.49)\end{array}$ & $\begin{array}{c}0.33 \pm 0.13^{\mathrm{ab}} \\
(0.15-0.67)\end{array}$ & $*$ \\
\hline Rotifera & $\begin{array}{l}0.78 \pm 0.14^{\mathrm{a}} \\
(0.51-0.98)\end{array}$ & $\begin{array}{l}0.62 \pm 0.20^{\mathrm{a}} \\
(0.31-0.97)\end{array}$ & $\begin{array}{l}0.56 \pm 0.17^{\mathrm{b}} \\
(0.27-0.81)\end{array}$ & $\begin{array}{l}0.48 \pm 0.13^{c} \\
(0.27-0.73)\end{array}$ & $* *$ \\
\hline Cladocera & $\begin{array}{l}0.44 \pm 0.04^{\mathrm{a}} \\
(0.36-0.51)\end{array}$ & $\begin{array}{l}0.47 \pm 0.14^{\mathrm{a}} \\
(0.26-0.82)\end{array}$ & $\begin{array}{l}0.33 \pm 0.08^{b} \\
(0.23-0.51)\end{array}$ & $\begin{array}{l}0.34 \pm 0.10^{\mathrm{b}} \\
(0.16-0.51)\end{array}$ & $*$ \\
\hline $\begin{array}{l}\text { Crustacean } \\
\text { larvae }\end{array}$ & $\begin{array}{l}0.33 \pm 0.06^{\mathrm{a}} \\
(0.27-0.46)\end{array}$ & $\begin{array}{l}0.35 \pm 0.11^{\mathrm{a}} \\
(0.19-0.57)\end{array}$ & $\begin{array}{l}0.27 \pm 0.05^{\mathrm{b}} \\
(0.18-0.37)\end{array}$ & $\begin{array}{c}0.21 \pm 0.06^{\mathrm{ab}} \\
(0.11-0.34)\end{array}$ & $*$ \\
\hline $\begin{array}{l}\text { Total } \\
\text { Phytoplankton }\end{array}$ & $\begin{array}{r}14.03 \pm 2.84^{\mathrm{a}} \\
(10.73-17.72)\end{array}$ & $\begin{array}{c}12.24 \pm 2.41^{b} \\
(12.62-18.92)\end{array}$ & $\begin{array}{l}8.29 \pm 2.24^{\mathrm{c}} \\
(6.11-11.23)\end{array}$ & $\begin{array}{l}9.89 \pm 2.13^{\mathrm{d}} \\
(5.61-10.30)\end{array}$ & $* *$ \\
\hline $\begin{array}{l}\text { Total } \\
\text { Zooplankton }\end{array}$ & $\begin{array}{l}3.98 \pm 0.45^{\mathrm{a}} \\
(3.50-4.75)\end{array}$ & $\begin{array}{l}4.35 \pm 0.41^{\mathrm{b}} \\
(3.54-5.35)\end{array}$ & $\begin{array}{l}2.84 \pm 0.43^{\mathrm{c}} \\
(2.39-3.36)\end{array}$ & $\begin{array}{l}3.14 \pm 0.23^{c} \\
(2.03-3.13)\end{array}$ & $* *$ \\
\hline Total Plankton & $\begin{array}{c}18.11 \pm 3.18^{\mathrm{a}} \\
(14.23-22.46)\end{array}$ & $\begin{array}{c}16.59 \pm 3.47^{\mathrm{b}} \\
(13.62-24.47)\end{array}$ & $\begin{array}{l}11.38 \pm 2.75^{\mathrm{c}} \\
(8.50-15.33)\end{array}$ & $\begin{array}{l}12.03 \pm 3.13^{\mathrm{d}} \\
(6.68-13.46)\end{array}$ & $* *$ \\
\hline
\end{tabular}

*Values indicate a significant difference at $5 \%$ significance level based on one way ANOVA followed by Tukey's test. **Values indicate a significant difference at $1 \%$ significance level based on one way ANOVA followed by Tukey's test. $\mathrm{NS}=$ Values are not significantly different $(p>0.05)$

Among zooplankton, Rotifera was the most abundant group representing $50 \%$ of total zooplankton. Branchionus was recorded as dominant genus. The lowest density of Rotifera was found in site IV and the maximum number was observed in site I. While highest mean abundance of Cladocera was found in site I with a range of $0.16 \times 10^{3}$ cells/L to $0.82 \times 10^{3}$ cells/L (Table II). On the other hand, Crustacea showed minimum concentration in different sites. The mean $( \pm \mathrm{SD})$ abundance of total phytoplankton varied from $11.38 \pm 2.75 \times 10^{3} \mathrm{cells} / \mathrm{L}$ to $18.11 \pm 3.18 \times 10^{3}$ cells/L with the highest value in site I and the lowest value in site III. On the other hand, the total zooplankton concentration was recorded higher in site II and lowest in site II. Almost similar pattern of percentages were observed in four study sites having higher values of phytoplankton in site I followed by site IV, site III and site II. 
Relationship of different physico-chemical parameters with plankton abundance: Relationships between different water quality parameters with the abundance of plankton community were analyzed by correlation matrix. Findings from the analysis revealed that the abundance of total phytoplankton and total plankton were negatively correlated with water temperature and transparency where positively correlated with water level, $\mathrm{pH}$, dissolved oxygen, total dissolved solids and total alkalinity. Abundance of total zooplankton also showed same relationship with different water quality parameters (Table III).

Table III. Correlation among different physico-chemical parameters and plankton groups

\begin{tabular}{l|c|c|c}
\hline Parameters & Total phytoplankton & Total zooplankton & Total plankton \\
\hline Water Temperature $\left({ }^{0} \mathrm{C}\right)$ & -0.380 & -0.225 & -0.360 \\
\hline Water level $(\mathrm{m})$ & 0.037 & 0.323 & 0.083 \\
\hline Transparency $(\mathrm{cm})$ & $-0.442^{* *}$ & $-0.569^{* *}$ & $-0.467^{* *}$ \\
\hline $\mathrm{pH}$ & $0.550^{* *}$ & $0.411^{*}$ & $0.534^{* *}$ \\
\hline Dissolved Oxygen $(\mathrm{ppm})$ & $0.433^{*}$ & 0.395 & $0.431^{*}$ \\
\hline Total dissolved solids $(\mathrm{ppm})$ & 0.205 & 0.353 & 0.231 \\
\hline Total alkalinity $(\mathrm{ppm})$ & $0.606^{* *}$ & $0.466^{*}$ & $0.591^{* *}$. \\
\hline
\end{tabular}

\section{Discussion}

The suitable water quality parameters are pre-requisite for a healthy aquatic environment. Different physical, chemical and biological factors are responsible for sustainable primary productivity of a water body (Rahman 1992). Findings from the present work revealed that the water temperature of the Gorveshwari river was found to fluctuate between $14.33-31.23^{\circ} \mathrm{C}$ considered as standard $\left(20\right.$ to $\left.30^{\circ} \mathrm{C}\right)$ for plankton production (Ahatun et al. 2020, Flura et al. 2016 and Alam et al. 2020). On the other hand, higher values of transparency was indicating presence of less clay, silt and dissolved organic compounds in the study river. Though Boyd et al. (1979) and Bhatnagar et al. (2004) reported the value of transparency below $30 \mathrm{~cm}$ generally acceptable for good fish production. Moreover, a slight fluctuation of dissolved oxygen was observed during the study period. Islam et al. (2017) was also reported low value of dissolved oxygen (2.0 to $5.6 \mathrm{ppm}$ ) in Rajakhali Canal of Karnaphuli river of Bangladesh. In addition, the recorded values of $\mathrm{pH}$ in the current research ranged between of 6.37-8.93. Similar observation also made by Ahmed et al. (2017) reporting $\mathrm{pH}$ concentration ranges between 7.4 and 9.5 in the river Buriganga of Bangladesh. Acidic $\mathrm{pH}$ reduces the growth rate, metabolic activity and other physiological activities of the fishes (Swingle 1967).

The alkalinity level did not exceed more than $40 \mathrm{ppm}$ throughout the study period. However in Korotoa river of Bogura, more than $80 \mathrm{ppm}$ alkalinity was recorded by Ahatun et al. (2020) and the lowest value was $50.66 \mathrm{ppm}$. Alkalinity provides a buffering capacity to aqueous system (Bhatnagar et al. 2004), so, the lower value of alkalinity might be the cause of lower carbon dioxide which is dissolved in the water. Whereas, TDS refer to the total amount of inorganic and organic substances, including minerals, salts, and metals in the water. In the present study, TDS was fluctuated within the range between 59.87-133.74 ppm. Similar observation (98.86 ppm) was also made by Ahatun et al. (2020) in Korotoa river of Bogura. 
WATER QUALITY ASSESSMENTS OF THE RIVER GORVESHWARI

Four major groups of phytoplankton were identified from Gorveshwari river and chlorophyceae was dominated over the phytoplankton group by 10 genus during the study period. Both phytoplankton and zooplankton are used in various ways as indicators of water quality (Kutama et al. 2014). High relative abundance of chlorophycae is an indicator of productive water (Ali et al. 2003). Sharma et al. (2016) recorded 34 species of phytoplankton representing three major group bacillariophyceae, chlorophyceae and cyanophyceae. Sarwade and Kamble (2014) also reported chlorophyceae as a dominating family with 22 species in Krishna river of India. On the other hand, euglenophyceae ranked as rear group of phytoplankton both in number and density. Arimoro et al. (2008) recorded only one genus of euglenophyceae. Among zooplankton, Rotifera were the most abundant group, representing more than 50\% of the total zooplankton. Among them Branchionus was the noted as a dominant genus in the present study. Genus Branchionus indicates eutrophic aquatic body (Sladecek 1983) and hence its abundant presence is considered as biological indicator for eutrophication (Nogueira 2001).

Different abiotic and biotic factors are reported as drivers of abundance, biomass and richness of rotifer population (Chen et al. 2011). Current study revealed that water level, DO, $\mathrm{pH}$ and alkalinity were positively correlated with phytoplankton abundance but negatively with water temperature, and transparency. It indicates that the abundance of plankton is higher in lower temperature and most dependent on $\mathrm{pH}, \mathrm{DO}$ and alkalinity. Moreover, several researchers have described temperature as a vital factor responsible for the growth of algae (Ramkrishnaiah and Sarkar 1982, Verma and Datta 1987, Kaushik et al. 1991, Bohra and Kumar 1999). However, some study also established positive correlations among water temperature, $\mathrm{pH}$, and alkalinity with total phytoplankton and negatively correlated with DO and transparency (Singh et al. 2013, Anamunda 2015).

All findings from the study are mostly providing some basic information about the water quality of Gorveshwari river in Dinajpur district. It can be concluded that the physico-chemical parameters and planktonic abundance of the Gorveshwari river were in the optimum level for fish production. However, further intensive investigation and experiments on biological factors are needed to save the biodiversity of this river for sustainable livelihood of the local fishing community.

\section{Literature Cited}

Ahatun, S., M.S. Islam, M.H. Kabir, M. Rehnuma and M.E. Hoque, 2020. Water quality and fish diversity in Korotoa river of Bogura, Bangladesh. Bangladesh J. Fish., 32(1): 60-72.

Ahmed, S., D. Roy, H. Uddin, S. Shil and M.S. Ahmed, 2017. Temporal analysis of phytoplankton diversity in relation to some physico-chemical parameters of the river Buriganga. Int. J. Fish. Aquat. Stud., 4(6): 526-530.

Alam, M.M., M. Kudrat-E-Zahan, M.H. Rahman and A.M. Zahid, 2020. Water quality assessment of Shitalakhya river. Asian. J. Fish. Aquat. Res., 6(1): 9-20.

Ali, M., A. Salam, S. Jamshaid and T. Zahra, 2003. Studies on biodiversity in relation to seasonal variation in water of river Indus at Ghazi Ghatt, Punjab, Pakistan. Pakistan. J. Biol. Sci., 6(21): 18401844.

APHA, 1992. Standard methods for the examination of water and wastewater (Vol. 2). American Public Health Association. 
Anamunda, A., 2015. Relationships between abundance of zooplankton and physico-chemical parameters in lake Mweru-Wantipa, Zambia. MS dissertation for the management of natural resources for sustainable agriculture of Sokoine University of Agriculture. Morogoro, Tanzania. 47p.

Arimoro, F.O., N.E. Rdema and R.O. Amaka, 2008. Phytoplakton community responses in a perturbed tropical stream in the Niger delta, Nigeria. Trop. Freshwat. Bio., 17(1): 37-52.

Bellinger, E.G., 1997. A Key to the Common Algae. The Institution of Water and Environmental Management. 138p.

Bhatnagar, A., S.N. Jana, S.K. Garg, B.C. Patra, G. Singh and U.K. Barman, 2004. Water quality management in aquaculture, In: Course Manual of summer school on development of sustainable aquaculture technology in fresh and saline waters, CCS Haryana Agricultural, Hisar (India), pp 203210.

Bohra, C. and A. Kumar, 1999.Comparative Studies of Phytoplankton in Two Ecologically Different Lentic Freshwater Ecosystems. Modern trends in Environmental Pollution and Ecoplanning (Ed. A. Kumar) ABP Publishers, Jaipur, pp. 220-242.

Boyd, C.E. and F. Lichtkoppler, 1979. Water Quality Management in Fish Ponds. Research and Development Series No. 22. International Centre for Aquaculture (J.C.A.A) Experimental Station Auburn University, Alabama, pp.45-47.

Chen, W., L. Liu, Q. Zhang and S. Dai, 2011. Effects of Nitrite and toxic Microcystis Aeruginosa PCC7806 on the growth of freshwater Rotifer Brachionus Calyciflorus. Bull. Environ. Contam. Toxicol., 86(3): 263-267.

Ferdoushi, Z., R. Hossain, M.J. Naher, O. Hassan and Y. Arafat, 2019. Limnological study of Shuksagaor Lake in Dinajpur District. Bangladesh J Fish., 31(1): 101-109.

Flura, M.A., N. Akhery, B.T. Mohosena and H.K. Masud, 2016. Physico-chemical and biological properties of water from the River Meghna, Bangladesh. Int. J. Fish. Aquat. Stud., 4(2): 161-165.

DoF, 2019. Yearbook of Fisheries Statistics of Bangladesh, 2018-19. Fisheries Resources Survey System (FRSS), Department of Fisheries, Bangladesh. Volume $36: 135 \mathrm{p}$.

Islam, M.R., N.G. Das, P. Barua, M.B. Hossain, S. Venkatramanan and S.Y. Chung, 2017. Environmental assessment of water and soil contamination in Rajakhali canal of Karnaphuli river (Bangladesh) impacted by anthropogenic influences: a preliminary case study. Appl. Water Sci., 7(2): 997-1010.

Kaushik, K.S., M.S. Agarkar and D.N. Saksena, 1991. Water quality and periodicity of phytoplanktonic algae in Chambal Tal, Gwalior, Madhya Pradesh. Bionature, 11(2): 87-94.

Kutama, R.M., M.M. Abubakar and M.L. Balorabe, 2014. The Plankton as indicators of water quality in Kusalla Reservoir: a shallow manmade lake. J. Pharmacol. Biol. Sci., 9(3): 12-15.

Lind, M.E. and A.J. Brook, 1980. A Key to the Common Desmids of the English Lake District. Freshwater Biological Association, 123p.

Nahid, N.H.M., M.N.A. Eliyana, S.M. Touhiduzzaman and M.N. Hossain, 2020. Seasonal availability and price margin of freshwater mud Eel (Monopterus cuchia) in Dinajpur, Bangladesh. United Int. J. Res. Tech., 1(12): 2582-6832.

Nogueira, M.G., 2001. Zooplankton composition dominance and abundance as indicators environmental compartmentalization in Jurumirim reservoir (Paranapanema river), Sao Paulo, Brazil. Hydrobiologia, 455: 1-18.

Pontin, R.M., 1978. A key to the freshwater planktonic and semi-planktonic Rotifera of the British Isles (No. 38). Hyperion Books.

Rahman, M.S., 1992. Water quality management: aquaculture. BRAC Prokashona, Mohakhali, Dhaka, Bangladesh, 84p.

Ramkrishnaiah, M. and S.K. Sarkar, 1982. Plankton productivity in relation to certain hydrological factors in Konar reservoir (Bihar). J. Inl.. Fish. Soc. India., 14(1): 58-68.

Sarwade, A.B. and N.A. Kamble, 2014. Plankton diversity in Krishna river, Sangli, Maharashtra. J. Ecol. Nat. Environ., 6(4): 174-181. 
Sharma, R.C., N. Singh and A. Chauhan, 2016. The influence of physico-chemical parameters on phytoplankton distribution in a head water stream of Garhwal Himalayas: A case study. The Egypt J. Aquat. Res., 42(1): 11-21.

Singh, M.R., G. Asha and K. Beeteswari, 2013. Physico-chemical properties of water samples from Manipur river system. Indian. J. Appl. Sci. Environ. Manage., 14(4): 85-89.

Sladecek, V., 1983. Rotifers as indicators of water quality. Hydrobiologia., 100(1): 169-201.

Swingle, H.S., 1967. Methods of analysis for waters, organic matter and pond bottom soils used in fisheries research Auburn Univ. Auburn, Ala., 119p.

Verma, P.K. and M.J.S. Dutta, 1987. Plankton community structure of Bandra Reservoir, Bhagalpur. Trop. Ecol., 28: 200-207.

(Manuscript received: 23 March 2021) 